\title{
Herbicide tolerance and water use efficiency in forest species used in degraded areas recovery programs
}

\author{
Tolerancia a herbicidas y eficiencia del uso del agua en especies forestales \\ utilizadas en programas de recuperación de zonas degradadas
}

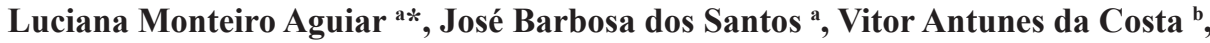 \\ Lílian Almeida Brito $^{\text {b }}$, Evander Alves Ferreira a, Israel Marinho Pereira ${ }^{\text {b }}$, Ignacio Aspiazu ${ }^{\text {c }}$ \\ *Corresponding author: ${ }^{\text {a }}$ Federal University of the Jequitinhonha and Mucuri Valleys, Faculty of Agricultural Sciences, \\ Departament of Agronomy, Rodovia MGT 367 - km 583, n 5000 Alto da Jacuba, 39100-000, Diamantina, Brazil, \\ lumonaguiar@hotmail.com \\ ${ }^{\mathrm{b}}$ Federal University of the Jequitinhonha and Mucuri Valleys, Faculty of Agricultural Sciences, \\ Departament of Forestry Engineering, Diamantina, Brazil. \\ c State University of Montes Claros, Departament of Agricultural Sciences, Janaúba, Brazil.
}

\begin{abstract}
SUMMARY
The use of tree species in recovery areas is a sustainable practice in many Brazilian regions. However, a major challenge is to manage invasive species and contain the herbicide residues applied in areas for recovery. Amid all the concerns about water crises, employing species with a better use of water in recovery programs of degraded areas on herbicides-contaminated sites becomes interesting. The objective of this study was to evaluate sensitivity to atrazine, clomazone and 2,4-D and water use efficiency in tree species. For this, an experiment was conducted under nursery and greenhouse conditions, in random blocks, consisting of a factorial arrangement: eight forest species (Eremanthus crotonoides, Richeria grandis, Protium heptaphyllum, Tapirira guianensis, Kielmeyera latrophyton, Calophyllum brasiliense, Inga striata and Caesalpinia ferrea) and three herbicide solutions, plus the control group. The total dose proposed for each product was twice the average recommended dose $\left(2.5 \mathrm{~kg} \mathrm{ha}^{-1}, 2.0 \mathrm{~L} \mathrm{ha}^{-1}\right.$ and $0.806 \mathrm{~kg} \mathrm{ha}^{-1}$, respectively, for atrazine, clomazone and 2,4-D), divided into six ten-day intervals each. After 80 days of the first application, phytotoxicity was evaluated, as well as chlorophyll, leaf temperature, leaf area and efficient use of water. Most species were negatively affected by the three herbicides. Protium heptaphyllum, K. latrophyton, I. striata and C. ferrea also experienced negative alterations in some variables, however, they were classified as the less sensitive group, allowing eventual use of the tested herbicides for chemical weed control in commercial plantations. Tapirira guianensis was the most efficient species in the use of water, regardless of herbicide presence.
\end{abstract}

Key words: atrazine, clomazone, 2,4-D, riparian zones.

\section{RESUMEN}

El objetivo de este estudio fue evaluar la sensibilidad a la atrazina, la clomazona y el 2,4-D y la eficiencia del uso del agua en especies de árboles. Para esto, se realizó un experimento en vivero e invernadero, en bloques al azar, mediante un arreglo factorial representado por la combinación de ocho especies forestales (Eremanthus crotonoides, Richeria grandis, Protium heptaphyllum, Tapirira guianensis, Kielmeyera latrophyton, Calophyllum brasiliense, Inga striata y Caesalpinia ferrea) y tres soluciones de herbicida, más el grupo de control. La dosis total propuesta para cada producto fue el doble de la dosis recomendada comercialmente $\left(2,5 \mathrm{~kg} \mathrm{ha}^{-1}, 2,0 \mathrm{~L} \mathrm{ha}^{-1}\right.$ y 0,81 $\mathrm{kg} \mathrm{ha}^{-1}$, respectivamente, para atrazina, clomazona y 2,4-D), divididas en seis intervalos de diez dias cada uno. Después de 80 días de la primera aplicación, se evaluó la fitotoxicidad, así como clorofila, temperatura de las hojas, área foliar y eficiencia del uso del agua. La mayoría de las especies se vio afectada negativamente por los tres herbicidas. Tapirira guianensis fue la especie más eficiente en el uso del agua, independientemente de la presencia de herbicidas. De esta manera, en medio de todas las preocupaciones sobre la crisis hídrica mundial, el empleo de estas especies con un mejor uso del agua en los programas de recuperación de áreas degradadas en sitios contaminados por estos herbicidas se vuelve interesante.

Palabras clave: atrazina, clomazona, 2,4-D, zonas ribereñas.

\section{INTRODUCTION}

In Brazil, the concern about preservationist political issues seek, primarily, to protect water resources by restoration of riparian forests. Currently the environmental adjustment of rural properties has been regarded as one of the main demands by the agricultural sector and environmental agencies. This is due to the term of the new Brazilian Forest Law and the implementation of the rural environmental record, in which the restoration of perma- 
nent preservation areas (PPA's) with conflicting land use and implementation or suitability of the legal reserve will be mandatory.

Riparian zones are situated in the interaction between aquatic and terrestrial environments and can often interconnect them by surface and subsurface hydrologic flow pathways (Naiman et al. 2005). The environmental impacts caused over the years, mainly by waste from agriculture, promoted a concern about the need for restoration of riparian forests, in order to improve water quality and habitat flow and to increase biodiversity. Restoring the vegetation of riparian areas can beneficially contribute to the ecosystem due to the reduction in water temperature, retention of sediments and nutrients and water treatment (Gregory et al. 1991).

In the restoration of degraded areas that are unfit for agriculture or show conflicting land use, such as the Permanent Preservation Areas (PPAs), the use of tree species is a sustainable practice in many Brazilian regions. However, in times of global climate change, water shortage leads to alterations in the physiological processes of plants, such as increased stomatal conductance, decreased transpiration and, consequently, affects the final process of photosynthesis. From this, the recommendation of tree species with efficient use of water, i.e., the ability of maintaining high photosynthetic rates for a smaller loss of water, through the opening and closing of stomata (Flexas et al. 2013) becomes an excellent choice for the reforestation of riparian forests. In parallel, such forests, directly associated with the health of hydrographic basins (Randhir and Ekness 2013), can become a variety of habitats for the biological communities and, in some situations, can contribute to the retention and degradation of pesticides. Bicalho et al. (2010) studied the distribution of herbicides in some of the Guarani aquifer riparian areas, in Brazil, and verified decreased contents of diuron, hexazinone and tebuthiuron in it, indicating that the buffer strip was effective in decreasing pesticide contamination before it reaches the surface water flow. The accumulation of organic residues in the rhizosphere, in riparian soils, could contribute to the proliferation of microbial mass and, therefore, these compounds may undergo adsorption and mineralization (Krutz et al. 2005).

Among the methods to recover an area are the natural regeneration and artificial regeneration, which can be through direct seeding or planting seedlings. As for natural regeneration, when there is a low impact level, just the exclusion of the degradation cause and the isolation of the area can promote restoration of the original vegetation. However, despite being low cost, in some cases it can be time consuming and, in unfavorable conditions, hinders a satisfactory regeneration. On the other hand, the artificial regeneration by direct seeding is also considered as low cost and aims at the insertion of species that are not able to colonize, in its early stages, during the recovery (Cole et al. 2011). The planting of seedlings, when satisfactory, has advantages such as increased diversity and composition of living organisms similar to the forest without degradation (Rodrigues et al. 2009). Saganuma and Durigan (2015), in a work to study the changes over the years in an area of the Brazilian Atlantic Forest undergoing restoration through planting of seedlings, concluded that the restored forests showed biomass increase capacity faster than that shown by natural forests in the same region.

The implementation of these forest restoration projects involve costs that are most often related to unsatisfactory methods of weed control and loss caused by this group. Weeds compete with the seedlings by slowing growth, in addition to possible colonization of areas with traces of native vegetation, making regeneration more difficult (Hooper et al. 2005). Even before taken to the field, the seedlings, initially grown in nurseries, are sensitive to the presence of weeds, which, in most cases, have superior ability to capture nutrients and water in both quantity and speed than seedlings. However, there should be a proper control, so that regeneration is not impaired. Thus, herbicides have been used for weed control in recovery areas (Machado et al. 2012).

The knowledge of selective products to native species will contribute to a better understanding about the more effective methods to control weeds, not only for reforestation, but also for business purposes and applications in agroforestry systems (Brancalion et al. 2009). However, herbicides used in annual crops are already being used in reforestation programs for weed control, evidencing the tolerance of some species. Brancalion et al. (2009) evaluated 25 native Brazilian species under the action of herbicides, and found that the sethoxydim is selective for 25 of tested species, the bentazon for 24 and the isoxaflutole for 20 ; demonstrating, thereby, that the number of potentially tolerant species to many herbicides is high. However, there are reports in literature about the sensitivity of Senna multijuga Mill. seedlings to the action of imazapyr and atrazine, of Trema micrantha (L.) Blume. under oxyfluorfen action (Ferreira et al. 2005) and Genipa americana L. under the influence of glyphosate (Gusmão et al. 2011), thus justifying the need for preliminary testing to confirm or not tolerance.

Herbicides such as atrazine (2-chloro-4-ethylamino6-isopropylamino-s-triazine), clomazone (2-[((2-chlorophenyl) methyl)-4,4-dimethyl-3-isoxazolidinone]) and 2,4-D (2,4-dichlorophenoxyacetic acid) are extensively used in Brazilian agricultural and commercial crops. In addition to information on the selectivity for possible application in those crops, the above herbicides, by being leachable, may reach the forest species, by drifting, but, above all, by the leaching effect, being absorbed by the roots. This possibility of contact may occur due to the direct application in planting areas (interrows) in annual crops grown between tree species, in the form of a consortium or in bands, or by the residual effect in the solution of the water table from applications in areas downstream of farmland. 
However, assuming the diversity of weeds found in environmental recovery areas and the premise of integrated weed management, which recommends rotating mechanisms of action, it is interesting to test other herbicides on the selectivity to the tree species that will be used. Thus, the search for species possibly tolerant to these products allows the management in recovery programs of areas that are degraded and/or contaminated by herbicides. In addition, amid concerns about the scarcity of water resources, the search for species that are also efficient in water use becomes interesting.

Based on these assumptions, this study aimed at evaluating physiological aspects of native tree species used in the recovery of areas contaminated with atrazine, clomazone and 2,4-D.

\section{METHODS}

The experiment was conducted in a nursery and a greenhouse belonging to the Faculty of Agricultural Sciences, Federal University of Jequitinhonha and Mucuri Valleys, campus Diamantina/MG. The seedlings were produced in the nursery belonging to the Department of Forestry, and the species used were Eremanthus crotonoides (DC.) Sch.Bip, Protium heptaphyllum (Aubl.) March, Tapirira guianensis Aubl, Richeria grandis Vahl., Kielmeyera latrophyton Saddi, Calophyllum brasiliense Cambess, Inga striata Benth and Caesalpinia ferrea (var. leiostachya). After being grown for about six months in the nursery, the seedlings were transplanted and cultivated in $8 \mathrm{dm}^{3}$ polyethylene vases. The substrate used in the experiment was a distrofic Red Latosol (typic haplorthox), with a sandy texture and $56.2 \%$ of sand, $36 \%$ of clay and $7.8 \%$ of clay, being properly limed and fertilized.

The experiment was conducted in a randomized block design, in a $9 \times 4$ factorial, with four replications. The first factor consisted of the eight forest species plus the soil maintained without vegetation, and the second, herbicides atrazine, clomazone and 2,4-D plus the soil without herbicide, totaling 36 treatments and 144 experimental units.

The herbicides atrazine, clomazone and 2,4-D were applied six times in ten day intervals, each application corresponding to $1 / 3$ of the commercially recommended dosage of $500 \mathrm{~g} \mathrm{ha}^{-1}, 360 \mathrm{~g} \mathrm{ha}^{-1}$ and $806 \mathrm{~kg} \mathrm{ha}^{-1}$, respectively. The fractioning of the total dose was intended to simulate leaching, since such compounds do not reach the groundwater in its entirety. For this, each application was made on contention dishes under the perforated vases to allow absorption of the herbicide solution by the soil. To estimate water use efficiency, abundant irrigation, always kept in the contention dishes, was measured throughout the experiment.

The variables analyzed to determine the tolerance of plants to herbicides were phytointoxication, total chlorophyll, leaf temperature, leaf area and efficient use of water.

Phytotoxicity was determined by means of visual symptoms on a scale of 0 to $100 \%$; in which 0 corresponds to no injury and 100 is plant death (SBCPD 1995). Total chlorophyll was measured with the aid of a SPAD-502 Plus Chlorophyll Meter, in $\mathrm{mg} \mathrm{m}^{-2}$, while leaf temperature was determined on the third leaf from top to bottom, using a Scan Temp Infrared Thermometer, in ${ }^{\circ} \mathrm{C}$, at 2 p.m. (GMT3 ). The leaf area was determined from the total measuring of the area formed by the leaves in $\mathrm{cm}^{2}$ with a CI-2-13 Laser Leaf Area Meter coupled to a CI-203 leaf feeder. The variable water use efficiency was determined by calculating the ratio of dry matter of shoots and total quantity of water supplied during the experiment, in $\mathrm{g} \mathrm{mL}^{-1}$, discounting evaporation.

Evaluations of intoxication, total chlorophyll and leaf temperature were made at the end of the experiment, ten days after the last application of herbicides. Eighty days after the first application, the material was collected and the leaf area was determined.

The obtained data were transformed into percentage compared to the control, since there were different species, thus, different development characteristics. Subsequently, the analysis of variance was performed, and the means among species, under the effect of each herbicide, when significant, were grouped according to the Scott-Knott test at a $5 \%$ level of significance. To analyze the difference to the control for each species among herbicides, Tukey's test was used at a $5 \%$ significance level.

\section{RESULTS}

Under the effect of atrazine, a chlorosis on leaves was observed and, throughout the experiment, all species have undergone some degree of visual intoxication. Superior visual intoxications, 47.50 , were observed for the species Richeria grandis (table 1). In the presence of clomazone, $R$. grandis also showed more important levels of visual intoxication with $67.50 \%$, followed by Tapirira guianensis, Inga striata and Caesalpinia ferrea with $37.5 \%, 45 \%$ and $35 \%$, respectively. Symptoms observed after the first application of clomazone consisted of pink colored upper leaves, which, after the last applications, became white due to the lack of pigment.

Under the effect of 2,4-D, there was no significant difference on this variable amongst species and the observed symptoms were low visual intoxication values, with mild wrinkling of leaves and no formation of lateral buds. Some species, at the end of the experiment, showed no visual symptoms, such as I. striata, K. latrophyton, $R$. grandis and T. guianensis. However, during the test, all species showed some type of intoxication, even in a small percentage.

For the variable total chlorophyll, considering the behavior of the species under the influence of each herbicide, the chlorophyll content (table 2) was different only in relation to the control for the $R$. grandis species under the influence of clomazone, with a reduction of $40.5 \%$, and 2,4-D, with an increase of $50.0 \%$. Regarding the comparison of each species under the influence of herbicides, only 
Table 1. Visual intoxication of plants submitted to fractioned doses of atrazine, clomazone and 2,4-D, equivalent to twice the commercially recommended average quantity (MAPA 2015)*.

Intoxición visual de plantas sometidas a dosis fraccionadas de atrazina, clomazona y 2,4-D, equivalentes al doble de la cantidad media recomendada comercialmente.

\begin{tabular}{|c|c|c|c|c|}
\hline \multirow{2}{*}{ Species } & \multicolumn{4}{|c|}{ Visual intoxication $(\%)^{\#}$} \\
\hline & Control & Atrazine & Clomazone & $2,4-\mathrm{D}$ \\
\hline Caesalpinea ferrea & $0 \mathrm{~b}$ & $20.00 \mathrm{Ba}$ & $35.00 \mathrm{Ba}$ & $08.75 \mathrm{Ab}$ \\
\hline Calophyllum brasilienses & $0 \mathrm{a}$ & $7.50 \mathrm{Ba}$ & $12.50 \mathrm{Ca}$ & $2.50 \mathrm{Aa}$ \\
\hline Eremanthus crotonoides & $0 \mathrm{a}$ & $11.25 \mathrm{Ba}$ & $11.25 \mathrm{Ca}$ & $13.75 \mathrm{Aa}$ \\
\hline Inga striata & $0 \mathrm{c}$ & $23.75 \mathrm{Bb}$ & $45.00 \mathrm{Ba}$ & $0.00 \mathrm{Ac}$ \\
\hline Kielmeyera latrophyton & $0 \mathrm{a}$ & $10.00 \mathrm{Ba}$ & $15.00 \mathrm{Ca}$ & $0.00 \mathrm{Aa}$ \\
\hline Protium hepthaphyllum & $0 \mathrm{a}$ & $15.00 \mathrm{Ba}$ & $1.25 \mathrm{Ca}$ & $11.25 \mathrm{Aa}$ \\
\hline Richeria grandis & $0 \mathrm{c}$ & $47.50 \mathrm{Ab}$ & $67.50 \mathrm{Aa}$ & $0.00 \mathrm{Ac}$ \\
\hline Tapirira guianensis & $0 \mathrm{~b}$ & $6.25 \mathrm{Bb}$ & $37.50 \mathrm{Ba}$ & $0.00 \mathrm{Ab}$ \\
\hline $\mathrm{CV}(\%)$ & \multicolumn{4}{|c|}{----------------- 58.11 --------------- } \\
\hline
\end{tabular}

\#Means followed by the same uppercase letter in the column belong to the same group, according to the Scott-Knott Criteria at $5 \%$ error probability. Means followed by the same lowercase letter in the line do not differ by Tukey's test at $5 \%$ probability of error. * Atrazine: $500 \mathrm{~g} \mathrm{ha}^{-1}$; Clomazone: $360 \mathrm{~g} \mathrm{ha}^{-1} ; 2,4-\mathrm{D}: 806 \mathrm{~g} \mathrm{ha}^{-1}$.

Table 2. Evaluation of total chlorophyll content of plants submitted to applications of the herbicides atrazine, clomazone and 2,4-D compared with their respective control $(100 \%)^{*}$ equivalent to twice the commercially recommended average quantity (MAPA 2015$) *$.

Evaluación del contenido total de clorofila de plantas sometidas a aplicaciones de los herbicidas atrazina, clomazona y 2,4-D, en comparación con su respectivo control $(100 \%)^{\#}$ equivalente al doble de la cantidad media recomendada comercialmente.

\begin{tabular}{lccrc}
\hline \multicolumn{1}{c}{ Species } & \multicolumn{4}{c}{ Chlorophyll content (\%) } \\
\cline { 2 - 4 } & Control & Atrazine & Clomazone & $2,4-\mathrm{D}$ \\
\hline Caesalpinea ferrea & $(47.58) 100 \mathrm{a}$ & $79.49 \mathrm{Aa}$ & $106.55 \mathrm{Ba}$ & $93.8 \mathrm{Ba}$ \\
Calophyllum brasilienses & $(45.48) 100 \mathrm{a}$ & $86.79 \mathrm{Aa}$ & $91.74 \mathrm{Ba}$ & $104.7 \mathrm{Ba}$ \\
Eremanthus crotonoides & $(44.33) 100 \mathrm{a}$ & $94.50 \mathrm{Aa}$ & $105.68 \mathrm{Ba}$ & $106.6 \mathrm{Ba}$ \\
Inga striata & $(43.25) 100 \mathrm{a}$ & $105.20 \mathrm{Aa}$ & $90.69 \mathrm{Ba}$ & $113.7 \mathrm{Ba}$ \\
Kielmeyera latrophyton & $(35.45) 100 \mathrm{a}$ & $105.71 \mathrm{Aa}$ & $99.01 \mathrm{Ba}$ & $104.6 \mathrm{Ba}$ \\
Protium hepthaphyllum & $(34.90) 100 \mathrm{a}$ & $85.74 \mathrm{Aa}$ & $105.87 \mathrm{Ba}$ & $104.4 \mathrm{Ba}$ \\
Richeria grandis & $(34.08) 100 \mathrm{~b}$ & $100.05 \mathrm{Ab}$ & $59.49 \mathrm{Ac}$ & $150.0 \mathrm{Aa}$ \\
Tapirira guianensis & $(29.60) 100 \mathrm{a}$ & $105.94 \mathrm{Aa}$ & $93.30 \mathrm{Ba}$ & $112.4 \mathrm{Ba}$ \\
\hline CV (\%) & & --------------17.89 & \\
\hline
\end{tabular}

R. grandis showed a change, with a reduction in chlorophyll content under the influence of clomazone.

The species $R$. grandis in the soil contaminated with 2,4-D showed an increase of $50.0 \%$, significantly differing from the others.

Regarding the behavior of the species for the temperature variable (table 3 ), in the different treatments, $R$. grandis showed a significant difference compared with the control when treated with clomazone, a reduction of $25.8 \%$. The other species did not differ from their respective controls in the different treatments.
The temperature analysis for each species, within the same treatment, showed that only under the effect of clomazone the species showed different responses. The means observed for temperature in plants treated with clomazone ranged from 74.21 to $109.9 \%$, and were classified into two groups according to the Scott-Knott criteria. The species $R$. grandis showed the lowest observed value (74.2\%), therefore, a decrease of $25.8 \%$ compared with its control. Protium heptaphyllum, T. guianenses, K. latrophyton and C. ferrea showed similar behavior and were in the same cluster. By contrast, the other group consisted of C. brasilien- 
ses, which presented the highest observed value, $109.9 \%$, followed by species $I$. striata and E. crotonoides, with 103.9 and $102.8 \%$, respectively.

Under the influence of atrazine and 2,4-D, no significant differences were detected between species as for the measured leaf temperature.

Table 4 shows the responses of the species for the variable leaf area in relation to treatments. Eremanthus cro- tonoides differed significantly from the control under the influence of atrazine and 2,4-D, with an increase of 229.8 and $183.4 \%$, respectively. Richeria grandis also showed similar behavior to the same herbicides, with increases of 117.4 and $130.8 \%$, respectively.

In the soils contaminated with atrazine and 2,4-D, regarding the species, the mean values varied, respectively, between 329.85 to $58.6 \%$ and 283.45 to $87.1 \%$. The spe-

Table 3. Evaluation of leaf temperature of plants submitted to the herbicides atrazine, clomazone and 2,4-D compared with their respective control (100\%) equivalent to twice the commercially recommended average quantity (MAPA 2015)*.

Evaluación de la temperatura foliar de plantas sometidas a los herbicidas atrazina, clomazona y 2,4-D, en comparación con su respectivo control $(100 \%)^{\#}$ equivalente al doble de la cantidad media recomendada comercialmente.

\begin{tabular}{lcccc}
\hline \multirow{2}{*}{\multicolumn{1}{c}{ Species }} & \multicolumn{4}{c}{ Leaf temperature $\left({ }^{\circ} \mathrm{C}\right)$} \\
\cline { 2 - 5 } & Control & Atrazine & Clomazone & $2,4-\mathrm{D}$ \\
\hline Caesalpinea ferrea & $(29.15) 100 \mathrm{a}$ & $97.60 \mathrm{Aa}$ & $89.53 \mathrm{Ba}$ & $95.71 \mathrm{Aa}$ \\
Calophyllum brasilienses & $(27.60) 100 \mathrm{a}$ & $98.91 \mathrm{Aa}$ & $109.96 \mathrm{Aa}$ & $95.83 \mathrm{Aa}$ \\
Eremanthus crotonoides & $(26.40) 100 \mathrm{a}$ & $99.81 \mathrm{Aa}$ & $102.84 \mathrm{Aa}$ & $101.89 \mathrm{Aa}$ \\
Inga striata & $(30.05) 100 \mathrm{a}$ & $92.34 \mathrm{Aa}$ & $103.99 \mathrm{Aa}$ & $100.33 \mathrm{Aa}$ \\
Kielmeyera latrophyton & $(31.50) 100 \mathrm{a}$ & $95.23 \mathrm{Aa}$ & $87.46 \mathrm{Ba}$ & $86.19 \mathrm{Aa}$ \\
Protium hepthaphyllum & $(29.10) 100 \mathrm{a}$ & $98.79 \mathrm{Aa}$ & $92.44 \mathrm{Ba}$ & $93.64 \mathrm{Aa}$ \\
Richeria grandis & $(28.50) 100 \mathrm{a}$ & $100.87 \mathrm{Aa}$ & $74.21 \mathrm{Bb}$ & $105.09 \mathrm{Aa}$ \\
Tapirira guianensis & $(30.45) 100 \mathrm{a}$ & $98.52 \mathrm{Aa}$ & $87.03 \mathrm{Ba}$ & $94.41 \mathrm{Aa}$ \\
\hline CV $(\%)$ & & ------------11.08 & --------- & \\
\hline
\end{tabular}

\# Means followed by the same uppercase letter in the column belong to the same group, according to the Scott-Knott Criteria at $5 \%$ error probability. Means followed by the same lowercase letter in the line do not differ by Tukey's test at $5 \%$ probability of error. Values in parenthesis in the "control" column refer to the absolute values, in ${ }^{\circ} \mathrm{C} . *$ Atrazine: $500 \mathrm{~g} \mathrm{ha}^{-1}$; Clomazone: $360 \mathrm{~g} \mathrm{ha}^{-1}$; 2,4-D: $806 \mathrm{~g} \mathrm{ha}^{-1}$.

Table 4. Leaf area of plants submitted to the herbicides atrazine, clomazone e 2,4- D compared with their respective control (100 \%) equivalent to twice the commercially recommended average quantity (MAPA 2015)*.

Área foliar de plantas sometidas a los herbicidas atrazina, clomazona y 2,4-D, en comparación con su respectivo control $(100 \%)^{\#}$ equivalente al doble de la cantidad media recomendada comercialmente.

\begin{tabular}{|c|c|c|c|c|}
\hline \multirow{2}{*}{ Species } & \multicolumn{3}{|c|}{ Leaf area $(\%)^{\#}$} & \multirow[b]{2}{*}{$2,4-\mathrm{D}$} \\
\hline & Control & Atrazine & Clomazone & \\
\hline Caesalpinea ferrea & (123.11) $100 \mathrm{a}$ & $62.61 \mathrm{Ca}$ & 106.06 Aa & $98.29 \mathrm{Ba}$ \\
\hline Calophyllum brasilienses & (304.38) $100 \mathrm{a}$ & $158.94 \mathrm{Ca}$ & $123.81 \mathrm{Aa}$ & $164.58 \mathrm{Ba}$ \\
\hline Eremanthus crotonoides & (459.06) $100 \mathrm{~b}$ & $329.85 \mathrm{Ab}$ & $164.55 \mathrm{Aa}$ & $283.45 \mathrm{Aa}$ \\
\hline Inga striata & $(1,470.46) 100 \mathrm{a}$ & $58.65 \mathrm{Ca}$ & $50.17 \mathrm{Aa}$ & $87.14 \mathrm{Ba}$ \\
\hline Kielmeyera latrophyton & (356.27) $100 \mathrm{a}$ & $110.72 \mathrm{Ca}$ & $99.53 \mathrm{Aa}$ & $134.38 \mathrm{Ba}$ \\
\hline Protium hepthaphyllum & $(1,144.30) 100 \mathrm{a}$ & $63.73 \mathrm{Ca}$ & $109.25 \mathrm{Aa}$ & $99.68 \mathrm{Ba}$ \\
\hline Richeria grandis & (397.84) $100 \mathrm{~b}$ & $217.40 \mathrm{Ba}$ & $62.66 \mathrm{Ab}$ & $230.84 \mathrm{Aa}$ \\
\hline Tapirira guianensis & $(2,365.18) 100 \mathrm{a}$ & $124.06 \mathrm{Ca}$ & $96.15 \mathrm{Aa}$ & $119.57 \mathrm{Ba}$ \\
\hline CV (\%) & & 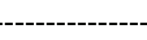 & --------- & \\
\hline
\end{tabular}

\# Means followed by the same uppercase letter in the column belong to the same group, according to the Scott-Knott Criteria at $5 \%$ error probability. Means followed by the same lowercase letter in the line do not differ by Tukey's test at $5 \%$ probability of error. Values in parenthesis in the "control" column refer to the absolute values, in cm. * Atrazine: $500 \mathrm{~g} \mathrm{ha}^{-1}$; Clomazone: $360 \mathrm{~g} \mathrm{ha}^{-1}$; 2,4-D: $806 \mathrm{~g} \mathrm{ha}^{-1}$. 
cies $E$. crotonoides, under the effect of atrazine, showed bigger leaf area, followed by $R$. grandis. These species showed the same behavior under the effect of the 2,4-D.

According to table 5, in the soil without herbicide, T. guianenses proved to be the most efficient in water use, standing out when compared with the others, while the C. ferrea was the less efficient. In the presence of atrazine, T. guianensis was the species that was more efficient for that variable, with $0.0055 \mathrm{~g} \mathrm{~mL}^{-1}$. In the soil with 2,4-D, again the $T$. guinensis stood out, with $0.0042 \mathrm{~g} \mathrm{~mL}^{-1}$, though not significantly different from $R$. grandis $(0.0055)$. In the soil contaminated with clomazone, this species also stood out, with 0.0036 , not differing from $C$. brasiliense (0.0032) and E. crotonoides (0.0027). In contrast, C. ferrea was the less efficient for all treatments.

Some herbicides strengthened the efficient use of water by some species. Richeria grandis, in the presence of atrazine and 2,4-D, showed an increase of 0.0014 and 0.0029 , respectively. Protium heptaphyllum presented an increase of 0.0013 when grown in soil with 2,4-D. For the K. latrophyton, 0.005 and 0.0013 for atrazine and 2,4-D, respectively. And, finally, 0.004 in soil with clomazone for C. brasiliense and 0.009 in soil with 2,4-D for I. striata.

\section{DISCUSSION}

The application of the equivalent to twice the recommended dose of each herbicide, considerably high, did not cause death of any species used in the experiment. Concentrations of this magnitude would hardly reach plants at once. However, assuming the constant applications in agricultural fields, it is likely that, in extreme situations, some plant species on the margins of such fields, can receive such load, justifying the overestimation.

All the species, during the experiment, suffered some degree of intoxication, however, some recovered from the symptoms. In this sense, tolerance, in more advanced stages, may be related to the increase of agents that are able to detoxify the plant through hydroxylation, dealkylation and conjugation reactions.

The second analyzed variable, chlorophyll, is a pigment with the function of capturing light energy for the photosynthesis, which convert it into chemical energy. Thus, this variable is related to adaptation to different environments due to its efficiency in photosynthetic estimate (Streit et al. 2005). In the presence of clomazone, for each species, $R$. grandis showed a change with reduction in chlorophyll contents, which inhibits the biosynthesis of carotenoids in plants, causing bleaching of the leaves. This decrease may be due to photooxidation of these molecules or the lack of such substances. This product is translocated from the root to the leaves, inhibiting the formation of other carotenoids (Braumann et al. 2007). The responsible for protecting chlorophyll from degradation by light works by inhibiting two parts, both in the production of chlorophyll, as in the pigments responsible for its protection and, therefore, there is a marked decrease in this variable. On the other hand, in the substrate contaminated by 2,4-D the $R$. grandis showed a higher increase in chlorophyll content than that shown by the other tested species.

Assuming that the $R$. grandis, under the effect of clomazone, showed decreased chlorophyll contents (table 2), consequently, due to the decrease in photosynthetic rate, it is possible the occurrence of a reduction in metabolic ac-

Table 5. Water use efficiency of plants submitted to the herbicides atrazine, clomazone e 2,4 - D compared with their respective controls (100\%) equivalent to twice the commercially recommended average quantity (MAPA 2015)*.

Eficiencia de uso del agua de plantas sometidas a los herbicidas atrazina, clomazona y 2,4-D, en comparación con su respectivo control (100 \% $)^{\#}$ equivalente al doble de la cantidad media recomendada comercialmente.

\begin{tabular}{lcccc}
\hline \multicolumn{1}{c}{ Species } & \multicolumn{4}{c}{ Water use efficiency $\left(\mathrm{g} \mathrm{mL}^{-1}\right)^{\#}$} \\
\cline { 2 - 5 } & Control & Atrazine & Clomazone & $2,4-\mathrm{D}$ \\
\hline Caesalpinea ferrea & $0.0007 \mathrm{Cb}$ & $0.0004 \mathrm{Dc}$ & $0.0008 \mathrm{Cab}$ & $0.0010 \mathrm{Ca}$ \\
Calophyllum brasilienses & $0.0028 \mathrm{Bb}$ & $0.0025 \mathrm{Bb}$ & $0.0029 \mathrm{Bb}$ & $0.0032 \mathrm{Aa}$ \\
Eremanthus crotonoides & $0.0022 \mathrm{Ba}$ & $0.0031 \mathrm{Ba}$ & $0.0026 \mathrm{Ba}$ & $0.0027 \mathrm{Aa}$ \\
Inga striata & $0.0027 \mathrm{Bb}$ & $0.0019 \mathrm{Cc}$ & $0.0036 \mathrm{Ba}$ & $0.0023 \mathrm{Bb}$ \\
Kielmeyera latrophyton & $0.0024 \mathrm{Bb}$ & $0.0029 \mathrm{Ba}$ & $0.0037 \mathrm{Ba}$ & $0.0024 \mathrm{Bb}$ \\
Protium hepthaphyllum & $0.0022 \mathrm{Bb}$ & $0.0015 \mathrm{Cb}$ & $0.0036 \mathrm{Ba}$ & $0.0023 \mathrm{Bb}$ \\
Richeria grandis & $0.0026 \mathrm{Bc}$ & $0.0040 \mathrm{Bb}$ & $0.0055 \mathrm{Aa}$ & $0.0021 \mathrm{Bc}$ \\
Tapirira guianensis & $0.0042 \mathrm{Ab}$ & $0.0055 \mathrm{Aa}$ & $0.0042 \mathrm{Ab}$ & $0.0036 \mathrm{Ab}$ \\
\hline CV (\%) & 26.1 & 19.3 & 37.8 & 27.1 \\
\hline
\end{tabular}

\# Means followed by the same uppercase letter in the column belong to the same group, according to the Scott-Knott Criteria at $5 \%$ error probability. Means followed by the same lowercase letter in the line do not differ by Tukey's test at $5 \%$ probability of error. * Atrazine: $500 \mathrm{~g}$ ha ${ }^{-1}$; Clomazone: $360 \mathrm{~g} \mathrm{ha}^{-1}$; 2,4-D: $806 \mathrm{~g} \mathrm{ha}^{-1}$. 
tivity, which may be related to decreased leaf temperature (table 3). For the other tested products, no significant differences among species were found. Confirming this expectation, Silveira (2013) concluded in his experiment on the interference of herbicides on physiological characteristics of cassava that, if leaf temperature does not differ statistically for the species, it can be inferred that the metabolic activity was also not significantly affected. However, in situations without water deficit, the application of herbicides, such as glyphosate, may be indicative of plant stress, which can cause less water in the leaf, favoring an increase in leaf temperature since this variable is directly related to the water potential of the plant.

In this experiment, it was observed that atrazine and 2,4-D intensified leaf growth for the E. crotonoides and $R$. grandis species. Leaf area is the photosynthetic plant surface and changes to the internal leaf conformation are directly related to the adjustment capacity of the species when in different environmental conditions. An answer to this can be to change the size of the leaves, i.e. leaf area. Thus, this variable can undergo drastic changes, e.g., when exposed to herbicides. However, the results found in literature are the negative effect of such herbicides on leaf area. Wall (1996), studying different doses of this herbicide in cotton, noted a variable reduction of $39 \%$ at the lowest dose and $78 \%$ at the highest dose corresponding to 1.5 to $24 \%$ of that recommended for cultivation of cereals, respectively. Moreover, the author observed inhibition of growth observed epinasty stem, petiole and leaf blade deformation.

Regulators act like "antigiberelins", with the formation of reduced internodes and smaller leaves. Plant regulators as the auxins interfere in plant tissues causing cell division, which can favor leaf expansion.

Another analyzed variable, the water use efficiency, is related to the behavior of gas exchanges and the variation of this parameter amongst the species, which is measured by the ratio between photosynthesis and transpiration. In degraded areas, the species are subjected to extreme situations regarding the acquisition of resources such as light, water, $\mathrm{CO}_{2}$ and nutrients (Puerta 2002). Some species have better capacity to adapt to these situations, using favorable mechanisms, as dropping leaves, using soil water reserves, as well as storing it in their trunks (Borchert 1998), keeping their photosynthetic rates. In this context, a species with an efficient use of water, such as T. guianensis in this experiment, with this resource becoming each time more scarce, would keep its development, since, according to Hessin et al. (2009), this capacity can be a strategy of the plant as a mechanism to adapt to drought conditions.

In a work carried out by Miranda et al. (2011), evaluating the influence of water potential in leaf phenology of tree species in altitude forests at Chapada Diamantina, Bahia, Brazil, the authors observed that the phenology of T. guianensis indicates a positive condition in relation to water, even under drought conditions. For having a low wood density, Borchert (1994) considers it as a good indicator of water storage in its branches and trunks. The use of $T$. guianensis in degraded areas recovery programs or sites contaminated by these herbicides becomes interesting.

\section{CONCLUSIONS}

The species Richeria grandis and Eremanthus crotonoides are more sensitive to the herbicides atrazine, clomazone and 2,4-D.

The species Protium heptaphyllum, Kielmeyera latrophyton, Inga striata and Caesalpinia ferrea also experience negative alterations in some variables, however, being classified as the less sensitive group, allowing eventual use of the tested herbicides for chemical weed control in commercial plantations.

Tapirira guianensis shows the most efficient water use, regardless of the presence of herbicide; the use of this species in degraded areas recovery programs or sites contaminated by these herbicides becomes recommended.

\section{ACKNOWLEDGMENTS}

To The State of Minas Gerais Research Foundation (Fundação de Amparo à Pesquisa do estado de Minas Gerais, FAPEMIG), the National Counsel of Technological and Scientific Development (Conselho Nacional de Desenvolvimento Científico e Tecnológico, $\mathrm{CNPq}$ ) and the Coordination for the Improvement of Higher Education Personnel (Coordenação de Aperfeiçoamento de Pessoal de Nível Superior, CAPES), for the financial support to develop this research.

\section{REFERENCES}

Bicalho STT, T Langenbach, RR Rodrigues, FV Correia, AN Hagler, MB Matallo, LC Luchini. 2010. Herbicide distribution in soils of a riparian forest and neighboring sugar cane Field. Geoderma 158(3): 392-397.

Borchert R. 1998. Responses of tropical trees to rainfall seasonality and its long-term changes. Climate Change 39(2): 381-393.

Borchert R. 1994. Soil and stem water storage determine phenology and distribution of tropical dry forest trees. Ecology 75(5): 1437-1449.

Brancalion PHS, I Isernhargen, RP Machado, PJ Christoffoleti, RR Rodrigues. 2009. Seletividade dos herbicidas setoxidim, isoxaflutol e bentazon a espécies arbóreas nativas. Pesquisa Agropecuária Brasileira 44(3): 251-257.

Brauman KA, GC Daily, TK Duarte, HA Mooney. 2007. The nature and value of ecosystem services: an overview highlighting hydrologic services. Annual Review Environment Resources 32: 67-98.

Cole RJ, KD Holl, CL Keene, RA Zahawi. 2011. Direct seeding of late-successional trees to restore tropical montane forest. Forest Ecology and Management 261(10): 1590-1597.

Ferreira FA, AC Davide, EM Alcântara, MS Motta. 2005. Efeito de herbicidas de pré-emergência sobre o desenvolvimento 
inicial de espécies arbóreas. Revista Brasileira de Herbicidas 4(1): 133 - 145 .

Flexas J, U Niinemets, A Gallé, MM Barbour, M Centritto, A Diaz-Espejo. 2013. Conductances Difusionais ao $\mathrm{CO}_{2}$ como um alvo para aumentar a fotossíntese e eficiência do uso da água fotossintética. Photosynthesis Research 117(1-3): 45-59.

Gregory SV, FJ Swanson, WA McKee, KW Cummins. 1991. An ecosystem perspective of riparian zones. BioScience 41(8): 540-551.

Gusmão GA, RMR Neto, OM Yamashita. 2011. Deriva simulada de glyphosate em plantas jovens de jenipapo (Genipa americana L.) Revista Brasileira de Herbicidas 10(1): 13-19.

Hessini K, JP Martínez, M Gandour, A Albouchi, A Soltani, C Abdelly. 2009. Effect of water stress on growth, osmotic adjustment, cell wall elasticity and water-use efficiency in Spartina alterniflora. Environmental and Experimental Botany 67: 312-319.

Hooper E, P Legendre, R Condit. 2005. Barriers to forest regeneration of deforested and abandoned land in Panama. Journal of Applied Ecology 42(6): 1165-1174.

Krutz LJ, SA Senseman, RM Zablotowicz, MA Matocha. 2005. Reducing herbicide runoff from agricultural fields with vegetative filter strips: A review. Weed Science 53(3): 353367.

Machado VM, Santos JB, Pereira IS, Cabral CM, Lara RO, Amaral CS. 2012. Controle químico e mecânico de plantas daninhas em áreas em recuperação. Revista Brasileira de Herbicidas 11(2): 139-147.

Naiman RJ, Décamps H, McClain ME. 2005. Riparia: Ecology, Conservation and Management of Streamside Commu- nities. Amsterdam, The Netherlands. Elsevier Academic Press. 430 p.

Miranda LAP, AP Vitória, LS Funch. 2011. Leaf phenology and water potential of five arboreal species in gallery and montane forests in the Chapada Diamantina; Bahia; Brazil. Environmental and Experimental Botany 70(2-3): 143-150.

Puerta R. 2002. Regeneração arbórea em pastagens abandonadas na região de Manaus em função da distância da floresta contínua. Scientia Forestalis 62: 32-39.

Randhir TO, P Ekness. 2013. Water quality change and habitat potential in riparian ecosystems. Ecohydrology and Hydrobiology 13(3): 192-200.

Rodrigues RR, RAF Lima, S Candolfi, AG Nave. 2009. On the restoration of high diversity forests: 30 years experience in the Brazilian Atlantic Forest. Biological Conservation 142(6): 1242-1251.

SBCPD (Sociedade Brasileira da Ciência das Plantas Daninhas, BR). 1995. Procedimentos para instalação, avaliação e análise de experimentos com herbicidas. Londrina, Brasil. 42 p.

Silveira HM, EA Ferreira, DV Silva, MDC Neto, FP Carvalho, JB Santos, AA Silva. 2013. Características fisiológicas de cultivares de mandioca após aplicação do mesotrione. Planta Daninha 31(2): 403- 409.

Streit NM, LP Canterle, MW Canto, LHH Hecktheuer. 2005. As clorofilas. Ciência Rural (Santa Maria) 35(3): 748- 755.

Suganuma MS, G Durigan. 2015. Indicadores de sucesso restauração em florestas tropicais ripárias usando vários ecossistemas de referência. Restauração Ecológica 23(3): 238-251.

Wall DA. 1996. Effect of sublethal dosages of 2,4-D on annual broadleaf crops. Canadian Journal of Plant Science 76(1): 179-185. 